\title{
The ecclesiastical situation of the first generation Roman Christians
}

\author{
A B du Toit \\ Associate: Research Unit for the New Testament \\ Faculty of Theology (Sec B) \\ University of Pretoria
}

\begin{abstract}
Forming part of a trilogy about the first generation Roman Christians, this article concentrates on the ecclesiastical aspect. From some scattered and relatively small groups, the numbers of Roman Christians increased markedly in the second half of the first century. According to Romans 16, Jewish Christians played a significant role in the initial period, although Gentile Christians were in the majority. Friction between these groups may have been a problem, but was not Paul's main concern. The Gentile Christians were mainly from a foreign background. Thus the first Christian community had a strongly cosmopolitan character. The plurality of house-churches was mainly due to practical factors, but social differentiation might have played a role. Meetings most probably took place in the ordinary rented apartments of insulae. Romans 16 renders a vivid picture of the leadership activities of Christian women and of Paul's enlightened position in this regard.
\end{abstract}

\section{INTRODUCTION}

This article links up with two others which are submitted for publication elsewhere. The one motivates inter alia why I have become convinced that Romans 16 could be used as a source for research regarding the first Christian community in Rome (Du Toit 1997a), and the other one dealing mainly with the origins and social circumstances of the Christians to whom Paul wrote his letter (Du Toit 1997b). However, the ecclesiastical situation of these Christians deserves special attention. It also seems to be a fitting theme to honour a long-standing friend and colleague of ours to whom the church of Jesus Christ, and the contribution we as New Testament scholars should make in this regard, always has been a priority. 


\section{THEIR NUMBERS}

We can only make an educated guess as to the numbers of Christians in Rome at the time when Paul wrote his letter to them. If we have to take into account the three house-churches, possibly five (vide infra), their numbers would not have been much more than a hundred. On the other hand, Tacitus mentions that in 64 AD Nero executed a large number (multitudo ingens) of Christians (Ann XV 44:4). This is corroborated by I Clement, which refers to a $\pi \circ \lambda \grave{v} \pi \lambda \hat{\eta} \theta \circ \varsigma$ (6:1). In both cases we have to reckon with the probability of rhetorical exaggeration. But even so, it seems likely that the growth of Roman Christianity accelerated significantly during the second half of the first century. In the last decades of the second century they were, according to Irenaeus (Adv Haer III 3:2), already the largest Christian grouping in the world.

One may perhaps ask in this regard whether the"separation between church and synagogue, which probably took place after the series of clashes between Jews and Christians in the late fourties and the resultant Edict of Claudius in $49 \mathrm{AD}$, did not have an influence on the strong increase of the Roman Christian population during the second half of the first century. One should not forget that, on the one hand, the Jewish synagogue provided a safe haven for incipient Christianity because of the official protection of Jewish faith by the state, but that on the other hand it restricted the expansion of Christianity because of the ethnic exclusiveness the outside world associated with Judaism. Although La Piana over-simplified the situation somewhat, there remains an important element of truth in his remarks about the 'marked individuality' and 'the impassable barrier' between Jews and non-Jews (La Piana 1927:205). Coupled to this, certain sections of the Roman empire at the time harboured a strong feeling of anti-Semitism (cf e g Sevenster 1975). Once its umbilical cord with Judaism was cut, Christianity could be much more readily accepted as an all-embracing faith and this would have favoured its expansion considerably.

\section{ETHNIC COMPOSITION}

My inquiry into the ethnic composition of the first Roman community is not because I am interested in the ethnic question as such, but due to its exegetical and theological relevance. As a matter of fact, the term 'ethnic' is used here through lack of a better one, the main question in this regard being the relationship between the Jewish and non-Jewish components of the original Christian community in Rome.

In principle the term 'Jewish' was at this stage a religious and not an ethnic designation (cf Solin 1983:613). Anybody who accepted the Jewish faith and way of life and went through the prescribed rituals was considered a member of the Jewish people. But in practise it remained to be an ethnic qualification to such an extent that identifying a person as a Jew almost invariably primarily referred to adherence to a specific ethnic group. 
Our best start would be with the Jewish population of first century Rome. Although the number of Jews in the caput orbis fluctuated in accordance with political and other factors, we do know that it was quite substantial. Leon (1995:135-136) has estimated that the Jews under Augustus must have numbered between 40000 and 50 000. Solin is more conservative. His figures are between 15000 and 40000 . Van der Horst (1991:80) accounts for a conservative 25000 . Other figures vary mostly beteen 30000 and 60000 (cf Solin 1983:698-699). Out of a total population of over one million (e g La Piana 1927:188; Oates 1934; Lampe 1989:116) this was not a significant proportion, but the attention given to these Jews by Roman writers shows that their presence was certainly felt. They were organized in several synagogues. According to Stern (1974:166-167), we can identify eleven such synagogues from Jewish epitaphs, while Lampe takes a maximum of fourteen (1989:367-368). In Trastevere (originally Transtiberinum), where the earliest substantial Jewish settlement took place (cf e $\mathrm{g}$ Philo Leg ad Gaium 155,157), and where the bulk of the Jewish population was concentrated even into the Middle Ages (Leon 1995:136), evidence of seven synagogues have been found, of which at least four can be dated before 54 AD (Stern 1974:166167).

It is generally agreed that these Jewish synagogues formed the natural startingpoint for the preaching of the Christian gospel (i a Wiefel 1970:71; Lampe 1989:3, 56; Dunn 1988:xlvii-xlviii). For sociological, theological and missionary-strategic reasons this was the usual practice adopted by the early Christian missionaries (cf Acts $11: 19-21 ; 13: 5,14,42052 ; 14: 1-6 ; 17: 1-7,10,17 ; 18: 4-7,19-21,26 ; 19: 8-9)$. The close original connection between Judaism and Christianity is substantiated by the fact that Jews and Christians originally lived in the same parts of Rome, especially in Trastevere and the urban tract of the Via Appia between the Almone stream and Porta Capina ((Lampe 1989:10-52).

That there was a definite Jewish element within the first Christian community of Rome is clear from Paul's greeting-list in Romans 16. He specifically mentions the Jewish lineage of Andronicus, Junia and Herodion ( $\mathrm{Rm} \mathrm{16:7,11).} \mathrm{There} \mathrm{were,}$ however, several more Jews among those greeted. In certain instances, Paul suppressed a reference to a person's Jewish origin in favour of other laudatory remarks. From Acts 18:2 we know that Aquila was a Jew and Prisca would hardly have been a non-Jew. Lampe (1989:58), who seems to under-estimate the Jewish element in the greeting-list, eliminates Maria (Rm 16:6) because this name was a well-known female form of the Latin Marius. But Maria is also a very typical and prevalent equivalent for the Hebrew Miriam. As happened in the case of Prisca and Aquila, Paul probably refrained from mentioning her ethnic origin because he had a different compliment for 
her. But even if the name Maria was of Latin origin in this specific case, it does not disqualify her as a Jewess, since Jews often adopted Roman names or Jewish-Roman double-names, Paul being a prime example of the latter.

Rufus (Rm 16:13) and Julia ( Rm 16:15) could also have been Jews. Lampe himself points out that these two typically Roman names were also used by Jews in Rome (1989:58 footnote 154). If the gospel of Mark must in some way be connected with Rome, it is highly probable that Rufus was the same person mentioned in Mark 15:21 as one of the two sons of Simon of Cyrene. This would most probably imply that he was a Jew and the same would then apply to his mother. Was it in Jerusalem that Paul experienced Rufus' mother as a mother to him too? It may be significant that Acts 6:9 includes people from Cyrene. This is a key verse in understanding the early Christian missionary movement since the Stephen circle, at least partly, would have emerged from the groups mentioned here and probably drew more converts from them later on (cf Paul himself). Did Simon and his family become Christians within this context? In that case they also belonged to the Jerusalem Hellenists who were dispersed, and Rufus and his mother eventually settled in Rome. There may even be an interesting addendum to this story. One would wonder what happened to Alexander, who is mentioned as the brother of Rufus. Why did he not also go to Rome? It might be an almost unbelievable historical coincidence, but it cannot be totally ruled out that the ossuary discovered in the Kidron valley outside Jerusalem and published in 1962 by Avigad, claiming on its lid to contain the bones of 'Alexander, the son of Simon', could be connected to this very same brother of Rufus (Van der Horst 1991:140-141). In that case, Alexander either died before his family left Jerusalem, or he might have preferred to stay there.

Since the name Tryfaena (cf Rm 16:12) has been documented for Jewesses outside Rome (Lampe 1989:58, footnote 154), she could also be of Jewish lineage. In that case the same would be probably true of Tryphosa, because the wording of Romans 16:12 gives the impression that they worked as a team.

Aristobulus was a well-known Jewish name which occurred in the Hasmonean as well as in the Herodian dynasties (see the overview in Reicke 1962:128). Those from his household would also have been Jewish (Cranfield 1979:792; Dunn 1988:896).

The list could even have included more Jews than those mentioned above. The practice of Jews adopting Latin or Greek names, or using double names, (a Jewish and a Latin one or even a Latin-Greek one) makes it impossible to determine exactly how many Jews were on Paul's greeting list. According to the statistical analysis done by Leon on the basis of Jewish epitaphs $46,35 \%$ of Roman Jews had only Latin names, 31,93 only Greek names, $13,14 \%$ only Semitic names and $8,58 \%$ had double names 
(Jewish-Latin or Latin-Greek) (cf Leon 1995:93-108). To be fair, however, Leon's statistics are of a later date. The Latin influence would have increased considerably since the time of Paul. But this would not change the fact that the Greek and Latin names in Romans 16 could refer to more Jews than we would otherwise have expected.

It must suffice to state that Jewish Christians constituted a substantial component of the Christian community in Rome and, judged by the way Paul qualifies them, contributed significantly to the religious leadership within the Christian community.

It would be unwise to use Romans 16 as a basis for determining the numerical ratio of Jews to non-Jews, first because we cannot determine their number exactly, and secondly since Paul, as a Jew, would naturally have met more travelling Roman Jews than non-Jewish Roman residents in the eastern parts of the empire.

The importance of the Jewish component of the Roman Christian community as reflected in Romans 16 does not therefore necessarily imply that Jews were in the majority. In reality, the opposite was the case. The majority of Paul's intended readers/hearers were without doubt Christians of non-Jewish origin. In Romans 1:6-7 as well as in Romans 1:13-15 he categorizes them without any hesitation as belonging to $\tau \grave{\alpha} \check{\varepsilon} \theta \nu \eta$. With the possible exception of Romans $9: 24$, he consistently distinguishes in chapters 9-11 between his readers, whom he addresses in the second person, and the Jewish people (Israel) to whom he refers in the third person. Especially Romans 9:3-5, $11: 1-2,7,13,17-24$ and $28-31$ can only with great difficulty be understood in the sense that Paul did not view the majority of his readers as non-Jews.

It would, however, also be a logical mistake to see these non-Jewish members of the Christian community as having been converted directly from paganism. This might have been the case with some of them. The vast majority of them would, however, have been sympathizers with Judaism in the sense that they were god-fearers, or perhaps, in a very few instances, proselytes. The numbers of the latter were far less than those of the former; Solin provides convincing reasons for this (cf Solin 1983:616617). We should add that people who have already converted fully to Judaism would be less inclined to re-convert to Christianity. In Acts we find numerous references to the god-fearers or god-worshippers (Ac 10:2, 22, 35; 13:16, 26, 50;16:14; 17:4, 17; $18: 7$; cf 13:43). After recent archeological discoveries, especially that of the Aphrodisias stone (see Reynolds \& Tannebaum 1987), there can be no doubt that the existence of this group was not a literary fiction by Luke (Schürer 1986:168; Van der Horst 1990:166-181; 1991:71; contra Kraabel 1981:113-126; Kraabel \& McLennan 1992). Josephus informs us that the Jews in Antioch drew 'crowds of Greeks' to their meetings (Bell Jud VII:45). The synagogues in Rome would also have been frequented by such sympathizing pagans. As happened elsewhere (cf Ac 10:44-48; 11:15-17; 13:43, 48, $16: 14-15 ; 17: 4 ; 18: 8)$, these would have proven fertile soil for the Christian gospel in Rome (cf Lampe 1989:60). 
We do not know much about possible fluctuations in the numerical ratio between Jewish and non-Jewish Christians. Some writers surmise that the Edict of Claudius diminished the numbers of Jewish Christians in Rome markedly, and, consequently, also their influence within the Christian community. On the other hand, their absence strengthened the hand of the non-Jewish Christians. This caused, according to these writers, confrontation on the return of the Jewish Christians to Rome (Wiefel 1970:7781; Solin 1983:663-664). Wiefel finds in this situation the Sitz im Leben of Romans (1970:81; cf also Solin 1983:663-664). Paul therefore writes Romans in order to encourage the non-Jewish Christians to live together with their Jewish brothers in one church.

Thus the search for the purpose of Romans came a full circle: Whereas F C Baur was of opinion that Paul wrote Romans in order to convince Jewish Christians to accept their brothers from a pagan background, Wiefel suggests exactly the opposite: Paul wanted to persuade non-Jews to open their hearts to their Jewish brothers.

Baur was certainly wrong. As has already been shown, Paul did not primarily address Jews but non-Jewish Christians. Wiefel, on the other hand, is correct in the sense that Paul certainly is much more sympathetic towards the Jews in Romans than in 1 Thessalonians 2:14-16. He is also more positive about the law than in Galatians. The question is, however, whether we can find traces of an anti-Judaistic attitude on the part of the non-Jewish Christians in Romans. Does the tension between the weak and the strong in Romans 14-15 not prove such an attitude? This is, however, not the case. Abstention from certain kinds of food and drink ( $R m$ 14:2, 15, 20-21) and the keeping of certain days ( $\mathrm{Rm} \mathrm{14:5)}$ were in no way restricted to Jews. Also god-fearers observed these customs (Lampe 1989:56-57). Some Jews probably belonged to the weak group and the sentiments of the latter were probably stimulated from a Jewish backgrourid. That would explain the concluding statement about the universal praise of God by Jews and non-Jews in Romans 15:7-12. But nowhere in the preceding argument can it be demonstrated that the two fronts in this dispute coincided with Jews and non-Jews respectively (cf Kümmel 1973:271, although not all his arguments are equally convincing). It is more acceptable that the weak consisted of Jews as well as exgodfearers who, although Christians, still sympathized with certain Jewish sentiments and customs.

Paul's warning in Romans 11:13-24 against a superior attitude on the part of nonJewish Christians may be a clearer indication of possible tension between non-Jewish and Jewish elements. The question is whether we have here a mere attitude problem or also a deep-going theological difference. We simply do not have the evidence to make a decision in this regard. One point is, however, very clear: If Paul wrote Romans 
with the main purpose of healing a fundamental rift between non-Jews and Jews, he did it so subtly in the major part of his letter that neither his non-Jewish nor his Jewish readers would have noticed it clearly enough! This was certainly not his style. The more positive way in which he presented the Jewish people and the law in Romans should rather be ascribed, in the first instance, to his intention of presenting his gospel as 'well-balanced' as possible - a gospel which has a place for Jews as well as nonJews, and secondly, because he wanted to convince his Jewish Christian readers of his own positive sentiments towards them, thus procuring also their goodwill towards him. He would also have intended addressing certain tensions among them, but these were not so serious that he deemed it necessary to make them his main concern.

Unfortunately we have no means of breaking down the ethnic composition of the non-Jewish component still further. Do we know what percentage of them were Greeks or Romans? The fact that the greeting-list contains sixteen Greek and seven Latin names (Solin 1983:663 footnote 178), should of course not entice us to find in this that there were as many Greeks and Romans, since names as such were at this stage seldomly a reliable indication of ethnic origin. We do know, however, that the Rome of the first century was a strongly cosmopolitan city, a real melting-pot of different groups, cultures and religions. This was especially true of Trastevere and Rome's southern regions. These were the places where the in-coming traffic via the Tiber, the Via Portuensis and the Via Appia entered the city (Lampe 1989:34) and where peregrini would take up their abode. Large numbers of liberti settled there. These were also the main centres where the first Christians lived (Lampe 1989:10-52). No wonder that foreigners originating from various countries and cultures formed the majority of the Roman Christian community (cf Lampe 1989:34,347). In spite of the increased romanizing of Christians, we find thatin the second century foreigners like Hermas, Justin, Marcion, Valentinus and Tatianus still play an important role in ecclesiastical life.

The dominating influence of foreigners in the first period of the Roman church is also demonstrated by the fact that the common ecclesiastical language was Greek (Lampe 1989:117-119, 128). The vast majority of first and second century documents pertaining to the Christian community in Rome are written in Greek. This agrees with the fact that most Jewish inhabitants of Rome spoke Greek, although they preferred, for understandable reasons, Latin names (Solin 1983:701-711) and that Greek was the common language of the plebs urbana. As a matter of fact, the majority of Rome's inhabitants at this stage spoke Greek, Latin being used mainly by the upper classes. 


\section{ECCLESIASTICAL STRUCTURING}

It certainly was not without reason that Paul did not refer to the Roman Christians as an $\dot{\varepsilon} \kappa \kappa \lambda \eta \sigma i \alpha$ in the adscriptio of his letter, as happens in several of his other letters. The reason for this could not have been that there was not, as yet, an established church in Rome, since he speaks in Romans 16:5 of a church which gathered in the home of Aquila and Prisca. Should the answer then rather be that there was more than one church in Rome? In that case, one could ask why he did not use the plural form as he did in Galatians (Gl 1:2). The churches addressed in Galatians, however, were situated in different cities. It is noteworthy that Paul presupposes at least two other groups which convened in houses, viz those of the 'Asyncritus'-group (16:14) and those around Filologus, Julia and others (16:15), but he refrains from calling them $\dot{\varepsilon} \kappa \kappa \lambda \eta \sigma i \alpha \iota$. Was this unintentional, or was the ecclesiastical structuring of these groups and their relationship to the church in Aquila's home not yet sorted out? Did Paul think that these various groups still had to be united in one regional church for Rome? We simply do not know. In referring to these groups we shall, for convenience's sake, nevertheless use the term 'churches'.

The plurality of house churches in Rome was caused by various factors. One of these was the geographical expansiveness of Rome and the related fact that there were concentrations of Christians in various parts. Another factor was the limitation of space, caused by the fact that they had to use ordinary homes. That these three groups - there could have been two more (cf Rm 16:10-11) - gathered regularly for worship, is clear from Paul's injunction that they should greet each other with the brotherly kiss (Rm 16:16).

In this regard it is worthwhile to draw attention to the fact that the plurality and independent existence of the Christian house churches in Rome corresponded to the pattern of the synagogues. I have already referred to the fact that in Trastevere alone there existed at least four synagogues in Paul's time. In contrast to Alexandria, where the Jewish synagogues were joined together by an etnarch, there was no overarching authority over them in Rome, which implies that they formed independent units.

On what social basis did these synagogues constitute themselves? Common interests and related group dynamics seem to have played an important role. The synagogue of the Augustesians, which was probably one of the oldest Jewish synagogues in Rome, was named for emperor Augustus who was a friend of the Jews and could perhaps have been the patron of this community (Schürer 1986:96; Leon 1995:142). In that case, the Jews forming this synagogue probably had some close relations to the imperial house. Although Leon (1995:142) energetically denies that they, or a strong element of them, would have been former slaves from the familia caesaris, this still remains a 
good guess (Schürer 1986:96). The same kind of affiliation would apply to the synagogogue of the Aggripesians and probably the Volumnesians (Schürer 1986:96). In these cases, the founder members of each of these synagogues would have been bound together by a common background and shared interests. In the case of the synagogue of the Calcaresians, its name may indicate that the bulk of its members were lime burners (Schürer 1986:97; Leon 1995:143). This would be most interesting, since it would mean that here members of the same profession formed a separate religious community. This possibility is rejected by Leon, who thinks it more likely that the name was derived from the area in Rome in which it was located (cf Leon 1995:143144). Schürer, on the other hand, thinks that the former possibility should not be summarily dismissed (see Schürer 1986:97 and especially footnote 32; also Van der Horst 1991:86-87). The synagogue of the Tripolitans was named after the place where its original members came from, viz either the Tripolis in Phoenicia or the one in North Africa. The same would apply to the synagogue of Elea, although we do not know for certain where this home-city was located (Van der Horst 1991:87). Much controversy surrounds the so-called synagogue of the Hebrews. The name may, however, imply that its founder members continued using Hebrew or Aramaic (cf Schürer 1986:97; other possibilities mentioned by Leon 1995:148; Van der Horst 1991:87-88). Leon (1995:148) rejects this because of the four relevant funeral inscriptions that have been found, three are in Greek. But the name of this synagogue would refer to its original members and not to its later adherents. Also, the synagogue of the Vernaclesians could refer to a specific social group, viz those Jews or Jewish ex-slaves who were born in Italy (but see the criticism of the latter possibility in Leon 1995:154-157). In spite of several remaining uncertainties, it therefore seems clear that social interests and other communal factors did play a role in the formation of some of the synagogues. In their case, ethnic considerations would of course not have played a role. Did ethnic or other social dynamics, apart from purely religious factors, play a role in the formation of the Christian churches of Rome?

Paul Minear's (1971:43) premise was that the different house churches are in some way, which he does not clarify Connected with different factions that were at odds with one another (Minear 1971:passim). He draws a picture of 'several congregations, separated from each other by sharp mutual suspicions' (Minear 1971:ix) and refers to 'heated antagonisms among the brothers' (Minear 1971:89). It would be wrong to state that ethnic connotations played a decisive role in Minear's view of how the Roman churches were constituted. The main factor would have been religious convictions, but these convictions were related to ethnic factors. He inferred no less than five different Christian factions in Rome: 
1) The weak in faith who condemned the strong in faith;

2) the strong in faith who scorned and despised the weak in faith;

3) the doubters;

4) the weak in faith who did not condemn the strong and

5) the strong in faith who did not despise the weak (Minear 1991:8-15).

Group 1 consisted, according to Minear, largely of converted Jews. Most members of group 2 would be either gentiles or libertinistic Jews. The doubters were Jewish Christians, 'uncertain of how much they should observe the Torah' (1971:12). Minear's ingenuity is more impressive than convincing. It would have put the cherry on the cake if he had been so bold as to identify the factions he discovered neatly with the 'five or six house congregations' (Minear 1991:7) he distinguished in Romans 16. His book is indeed a glaring example of illegitimate mirror reading. It may, however, contain a grain of truth (vide infra).

Jeffers (1991:41-42), who works more from a social historical perspective, is of the opinion that the church in the home of Prisca and Aquila was frequented by Jewish Christians, and the two mentioned in Romans 16:14 and 15 largely by Greek-speaking gentiles who were slaves or former slaves. He thinks that two other house churches may be addressed in Romans 16:10-11, and that these slaves or freedmen probably formed their own house congregations. Also, in the case of Jeffers it would be wrong to state that in his view purely ethnic connotations played a decisive role. It does seem however, that he reckons with ethnico-religious considerations as well as, in the case of freedmen and slaves, some other shared social features.

What may be true in both of the pictures drawn above is that not only geographical and other practical factors played a role in the formation of the different housechurches in Rome. It is quite possible that, in conjunction with religious factors, certain ethnic and social affinities contributed to a spontaneous grouping in different house-churches. The church in the house of Prisca and Aquila may have been frequented primarily by Jewish Christians, while some of the other house-churches could have been the result of a natural coming together of Christians from a servile background. But all this is mere guesswork. And it must also be stressed that due to the de-nationalizing influence of Hellenism over centuries, as well as different political, economic and social forces, ethnicity was not at all a major factor among the Roman plebs urbana. Concerning the theory that Paul's main purpose in writing Romans was to address antagonism between various Christian groups, I have already stated my case (vide supra). 
What is also important in this regard is that the existence of a plurality of housechurches lessened the possibility of friction and at the same time provided space for a variety of theological accents and eventually even for theological pluralism (see Lampe 1989:323-339, 347; also Jeffers 1991, although his sharp delineations may not be correct).

In spite of the independent co-existence of these house churches, they still kept close contact with one another. Paul is so sure that his letter will reach all of them that he does not even give an injunction in this regard. He also addresses them as one group. They may even have met regularly. Dunn, for instance (1988:893), conjectures that they held monthly meetings.

It is noteworthy that I Clement uses the single form $\dot{\varepsilon} \kappa \kappa \lambda \eta \sigma i \alpha$ in his adscriptio. He speaks of 'the church of God which dwells in Rome'. An abstract church concept could be at work here. More probably, the various house-churches experienced themselves more and more, in line with what Paul may have hoped, as cells of one common Roman church (cf Lampe 1989:33). In spite of their theological differences, they used to send each other the eucharist and administered financial aid for needy foreign churches collectively (Lampe 1989:335). Initial spiritual communion brought increasing cooperation, which eventually led to the monarchic episcopate and one unified church.

\section{PLACES OF WORSHIP}

The romantic idea that Roman Christianity was a 'church of the catacombs' and convened regularly in these burial-places for their services is a myth. The first Roman Christians came together in the everyday living quarters of better-off households. Normally they would meet in the main room of an apartment in an insula, spacious enough to accommodate say about fifteen to twenty five persons. Such would have been the meeting-place in the home of Aquila and Prisca. In the second century, Justin declares that Christians came together 'where they preferred and where it was possible' (Act Just 3; cf Dial 47:2), and mentions one such meeting-place: it was situated above the bath of a certain Myrtinus. In later, more favourable circumstances, the lord of a domus would provide a copiously decorated room for this purpose (Petersen 1969:270). The custom to set apart rooms in secular buildings specifically for cultic purposes, began only in the early third century, and the so-called title-churches, i e locations for worship named after the person who owned the title-deed of the specific building (the name was displayed at the entrance), still later (Petersen 1969:266-267).

\section{THE ROLE OF WOMEN IN ROMAN CHURCH LIFE}

An analysis of the ecclesiastical community in Rome in the fifties of the first century A $\mathrm{D}$ will be incomplete if we do not give attention to the leadership role of women in 
Romans 16, and by implication in Roman church life. Romans 16 can be called the New Testament chapter about Christian women. Nowhere else are we introduced to more ecclesiastically active Christian women than here.

In this context we can set aside Phoebe (16:1-2), although her role within the church of Cenchreae, and her strong commendation by Paul, fits in perfectly with what the apostle has to say about the Roman Christian women. To be true, among the twenty four Christians mentioned by name (Aristobulus and Narcissus were probably not Christians), we hear of only seven female ones: Prisca, Mary, Junia (sic!), Tryphaena, Tryphosa, Persis and Julia. Two others are also referred to, but not identified by name: The mother of Rufus and the sister of Nereus. This amounts to only about one third of the greeting list. But the picture changes at a closer reading. It becomes clear that these women were much more active in the gospel service than the men. Of six of those mentioned by name, Paul declares that they were actively engaged in spiritual work. Only Julia does not receive such an accolade. Of Mary and Persis we hear that they have 'laboured much' ( $\pi \circ \lambda \lambda \grave{\alpha} \dot{\varepsilon} \kappa o \pi i \alpha \sigma \varepsilon \nu)$, a compliment granted to no male believer. Prisca is not only mentioned first on the greeting list, but also before her husband Aquila (cf for this also Ac 18, 8, 26; $2 \mathrm{Tm}$ 4:19; differently Ac 18:2; 1 Cos 16:19). The latter feature has often drawn attention. Wayne Meeks (1983:59), is of the opinion that she appears first because of her higher social status. Dunn (1988:892) reckons with the same possibility, but adds that she could have been the dominant or the financially stronger person, or the brains behind their tentmaker's enterprise. But surely Paul is writing here within the context of a Christian community, and the norm he applies is that of Christian service. Therefore the reason why her name appears before that of Aquila, and in fact in the important first slot of the greeting-list, would obviously be that she was more prominent in her gospel service than her husband (Lampe 1989:451-452; see also Schüssler Fiorenza 1978:156-157; Murphy-O'Connor 1992:42). That Prisca must have been a remarkable woman and missionary worker is clear. Together with her husband they gave shelter to Paul in Corinth, and accommodated house churches in Ephesus (1 Cor 16:19) and Rome (Rm 16:5). When Apollos came to Ephesus, they 'instructed him more precisely' (Ac 18:26). They 'risked their lives' for Paul ( $R m$ 16:4), probably by taking up his cause while he was in prison in Ephesus, fearing for his life (cf 1 Cor 15:32; 2 Cor 1:8-10). In this way and for other reasons ( $\mathrm{g}$ offering the use of their home) they earned the gratitude of 'all the gentile churches' (Rm 16:4). In all this, Prisca probably was the stronger and more active figure.

The case of Junias/Junia, mentioned in Romans 16:7 alongside Andronicus, provides us with one of the most revealing examples of the decisive role of the exegete's predisposition in reading texts. Text-critically, the feminine name Junia is certainly to be preferred to the masculine Junias (cf Lampe 1989:137, 452; Brooten 


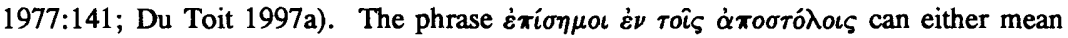
'outstanding in the eyes of the apostles' or 'outstanding among the apostles'. As it is, the latter understanding is the more obvious, which explains why male chauvenism would be inclined to protest. The formulation of this phrase, as well as the fact that they were Christians before Paul, could connect them to the circle of Hellenistic Christians in Jerusalem. They propably were a missionary couple who proclaimed the gospel part-time like Prisca and Aquila. If Junia was indeed designated here as an apostle in the more traditional sense of the word, this would add an exciting new perspective to the role of women in the early church. It should, however, be kept in mind that the term 'apostle' can be used in various senses in the New Testament (cf e $\mathrm{g}$ Schlüssler Fiorenza 1977:135-140). It is at any rate clear that Paul holds the person and work of Junia in very high esteem. In the course of her missionary endeavour together with Andronicus, they even became Paul's 'fellow prisoners', which could either mean that they shared the same fate as he did, or, more probably, that they shared the same prison. Exactly where we do not know.

Romans 16 not only provides us with an extremely important insight into the pioneering role of women in Roman church life, it also gives us an invaluable glance into Paul's own view of the importance of women within church context. The fact that he mentions and commends them so prominently, reveals his own enlightened view in this regard. This is not the time and place to discuss Paul's attitude towards women in detail. There certainly are other sections in his correspondence which indicate that a balanced assessment of his position is not that simple. Romans 16 shows, however, that at least in certain respects, Galatians 3:28 was not mere abstract theologizing for him. As was the case with slavery, he had not as yet drawn his basic insights to their logical conclusions. Nevertheless, he had in certain respects already broken with almost indestructable prejudices. In this he showed himself far ahead of his time.

Fourty years later, in I Clement, there is a different writer and a different spirit at work (cf Lampe 1989:121). The readiness of Roman Christian women to die as martyrs (6:1) is applauded. And yet the best thing they could do was to perform 'manly deeds': 'Many women, being strengthened through the grace of God, have performed many manly deeds' (55:3). The typical condescending male attitude towards women is at work. In 1:3 the obedience of women is highlighted and their terrain is limited to the household. In 21:7, the qualities towards which women should be guided are their 'lovely disposition of purity', their 'sincere affection of gentleness', their 'moderation of their tongue through their silence' and their love. Nowhere mention is made of an active part in church life, let alone a leading role. Dunn (1988:900) is of 
opinion that this restrictive view on the participation of women is a reaction to the greater charismatic liberty of the earlier years. Be it so, one cannot help wondering how much differently church history would have developed, had the much less bigoted Pauline approach, as witnessed in Romans 16, carried the day.

\section{Works consulted}

Brooten, B 1977. 'Junia ... outstanding among the apostles' (Romans 16:7), in Swidler, L \& Swidler A (eds), Women priests: A Catholic commentary on the Vatican declaration, 141-144. New York-Ramsay-Toronto:Paulist Press.

Cranfield, J C B 1977. The Epistle to the Romans, II. 2nd ed. Edinburgh: Clark. (ICC.)

Dunn, J D G 1988. Romans I-II. Dallas:Word Books. (WBC 38A.)

Du Toit, A B 1997a. Tekskritiese en aanverwante probleme in Romeine 14-16. Aangebied vir publikasie in NGTT XXXVIII.

- 1997b. 'God's beloved in Rome' ( $\mathrm{Rm}$ 1:7). The genesis and socio-economic situation of the first generation Christian community in Rome. Presented for publication in Neotestimentica 31.

Jeffers, J S 1991. Conflict at Rome: Social order and hierarchy in Early Christianity. Minneapolis: Fortress.

Käsemann, E 1974. An die Römer. 3. Aufl. Tübingen: J C B Mohr.

Kraabel, A T 1981. The disappearance of the God-Fearers. Numen 28, 113-126.

Kraabel, A T \& MacLennan, R S 1992. The God-Fearers - a literary and theological invention, in Overmann, $\mathrm{J}$ A \& MacLennan, $\mathrm{R} S$ (eds), Diaspora Jews and Judaism: Essays in honor of, and in dialogue with, A Thomas Kraabel, 47-53. Atlanta: Scholars Press. (Diaspora Jews and Judaism 41.)

Kümmel, W G 1973. Einleitung in das Neue Testament. Heidelberg: Quelle \& Meyer. Lampe, P 1989. Die stadtrömischen Christen in den ersten beiden Jahrhunderten. 2. Aufl. Tübingen: J C B Mohr. (WUNT 2. Reihe 18.)

La Piana, G 1927. Foreign groups in Rome during the first centuries of the empire. HTR XX, 183-403.

Leon, H J [1960] 1995. The Jews of ancient Rome. Peabody: Hendrickson.

Meeks, W 1983. The first urban Christians. London:Yale University Press.

Minear, P S 1971. The obedience of faith. London: SCM Press. (SBT 19.)

Murphy-O'Connor, J 1992. Prisca and Aquila. BiRe 8, 40-51.

Oates, W J 1934. The population of Rome. CP XXIX, 101-116.

Petersen, J 1969. House-churches in Rome. VigChr 23, 264-272.

Reicke, B 1962. 'Aristobulus'. Biblisch-Historisches Handwörterbuch, I, c.128. Göttingen: Vandenhoeck \& Ruprecht. 
Reynolds, J \& Tannenbaum, R 1987. Jews and Godfearers at Aphrodisias. Cambridge: Cambridge University Press. (Cambridge Philological Society Supplementary 12.)

Schürer, E 1986. The history of the Jewish people in the age of Jesus Christ, III/1. Edinburgh: Clark.

Schüssler Fiorenza, E 1977. The apostleship of women in Early Christianity, in Swidler, L \& Swidler A (eds), Women priests: A Catholic commentary on the Vatican declaration, 135-140. New York:Paulist Press.

1978. Women in the pre-Pauline and Pauline churches. USQR XXXIII, 153165.

Solin, H 1983. Juden und Syrer in der römischen Welt, in Temporini, H \& Haase, W (Hrsg), Aufstieg und Niedergang der römischen Welt, II. Principat 29/2, 587-789. New York: De Gruyter.

Sevenster J N 1975. The roots of pagan anti-semitism in the ancient world. Leiden: Brill. (NTS XLI.)

Stern, M 1974. The Jewish diapora, in Safrai, S \& De Jonge, M (eds), The Jewish people in the first century: Compendia rerum Iudaicarum ad Novum Testamentum, 1, 117-183. Assen: Van Gorcum.

Van der Horst, P W 1990. Jews and Christians in Aphrodisias in the light of their rela tions in other cities of Asia Minor, in Essays on the Jewish world pf Early Christianity, 166-186. Freiburg: Universitätsverlag. (NTOA 14.) 1991. Ancient Jewish epitaphs. Kampen: Kok Pharos.

Wiefel W 1970. Die jüdische Gemeinschaft im antiken Rom und die Anfänge des römischen Christentums. Jud. XXVI, 65-87. 